\title{
PENGARUH PEMBELAJARAN SENTRA SENI DAN KREATIFITAS TERHADAP PERKEMBANGAN SOSIAL EMOSIONAL ANAK KELOMPOK A DI RA ROUDLOTUL HAMDI REMBANG PASURUAN
}

\author{
Gusmaniarti \\ Dosen Universitas Muhammadiyah Surabaya \\ Email: gusmaniarti01@gmail.com
}

\begin{abstract}
ABSTRAK
Studi ini mengangkat tentang pengaruh pembelajaran sentra seni dan kreativitas terhadap perkembangan sosial emosional anak usia dini khususnya usia 4-5 tahun. Kesenjangan antara hasil yang di dapat dengan kenyataan yang ada di lapangan untuk mengembangkan kemampauan sosialemosional anak menjadi latar belakang penelitian pembelajaran sentra khususnya sentra seni dan kreativitas dapat membantu perkembangan sosial emosional anak karena saat bermain sentra seni dan kreativitas misal : dalam kegiatan berkreasi dan beriamajinasi dengan teman- temannya anak lebih intens dalam berkomunikasi dan bersosialisasi dan menciptakan suasana pembelajaran yang menyenangkan.

Metode penelitian yang di pakai adalah penelitian kuantitatif dengan menggunakan satu variabel bebas yaitu perkembangan sosial emosional anak. Sedangkan populasinya adalah semua siswa kelompok A dan kelompok B di RA Roudlotul hamdi Rembang dengan sampelnya 20 anak di kelompok A.yang mana sampel ini nanti di bagi 2 kelompok experimen dan kelompok kontial.

Uji Statistik yang di gunakan adalah uji validitas menggunakan rumus korelasi product momen,uji rellabilitas menggunakan alpha clonbach,uji normalitas wilcoxon signed rank dan uji hipotesis menggunakan analisis wilcoxon.

Dilihat dari angka - angka statistik yang di hasilkan maka peneliti mengumpulkan ada pengaruh pembelajaran sentra seni dan kreativitas terhadap perkembangan sosialemosional anak dengan skor rata-rata yang muncul sebelum treatmen (Preetest) adalah 26,00 dan skor rata-rata yang muncul setelah treatmen (Posttest) adalah, 356,00.
\end{abstract}

Kata kunci: Pembelajaran sentra seni dan kreativitas,Perkembangan sosial emosional anak

This study raised about the influence of learning center of art and creativity on emotional social development of early childhood, especially age 4-5 years. The gap between the results can be with the reality in the field to develop the social capacities of children into the background of learning center research, especially the center of art and creativity can help the emotional social development of children because when playing art and creativity centers for example: in the creative activities and beriajinasijinasi with friends - his friends are more intense children in communicating and socializing and creating a fun learning atmosphere.

The research method used is quantitative research using one independent variable that is emotional social development of children. While the population is all the students of group A and group B in RA Roudlotul hamdi Rembang with a sample of 20 children in group A.which this sample will be divided into 2 experimental groups and contial group.

The statistic test used is the validity test using the moment product correlation formula, rellability test using alpha clonbach, wilcoxon signed rank normality test and hypothesis test using wilcoxon analysis. Judging from the statistical figures generated, the researcher collects the influence of learning center of art and creativity on the sociocosional development of children with the average score that appears before the treatments (Preetest) is 26.00 and the average score that emerged after the treatmen (Posttest ) Is, 356.00.

Keywords: Learning center of art and creativity, social development of children emotional 


\section{PENDAHULUAN}

Usia dini merupakan periode emas (the golden age) bagi perkembangan anak untuk memperoleh proses pendidikan. Periode emas ini menurut (Slamet Suyanto, 2005:6), merupakan saatsaat berharga bagi seorang anak untuk mengenali berbagai aspek pertumbuhan dan perkembangan baik fisik dan motorik, perkembangan moral (termasuk kepribadian, watak, dan akhlak), sosial, emosional, intelektual, dan bahasa juga berlangsung sangat pesat. Tujuan pendidikan yang terdapat di dalam standar kompetensi di Taman Kanak-kanak tercantum tujuan pendidikan yaitu membantu mengembangkan berbagai potensi anak baik jasmani dan rohani yang meliputi nilai agama dan moral, sosial emosional, kognitif, bahasa, fisik motorik dan seni sebagai sarana atau media untuk menumbuhkembangkan beberapa kemampuan seperti kemampuan berpikir, kreativitas, dan keterampilan. Adapun tujuan program kegiatan belajar Lembaga TK/RA adalah membantu meletakkan dasar ke arah perkembangan sikap, pengetahuan keterampilan, dan daya cipta anak didik untuk menyesuaikan diri dengan lingkungan dan pertumbuhan serta perkembangan selanjutnya.

Kreativitas seni pada anak usia dini seharusnya sudah berkembang secara optimal karena kreativitas merupakan hal penting pula dalam kehidupan. Kreativitas membuat manusia lebih produktif. Selain itu juga kreativitas dapat meningkatkan kualitas hidup serta dapat mempermudah mencari jalan keluar dari sebuah permasalahan (problem solving). Menurut Sumanto (2005: 11), kreativitas seni adalah bagian dari kegiatan berproduksi atau berkarya seni termasuk dalam bidang senirupa. Kreativitas seni diartikan sebagai kemampuan menemukan.

Penelitian mengambil data dari RA Roudlotul Hamdi Rembang untuk memenuhi tugas akhir penelitian. Banyak Murid di RA Roudlotul hamdi Rembang Yang masih belum berkebang dalam kecerdasan emosionalnya khususnya dalam hal kemandirian anak.

Ketika anak sedang melaksanakan tugas atau kegiatan bermain sambil belajar di sentra seni, ada beberapa anak yang kurang bersosialisasi dengan teman lain dan lebih asyik dengan kegiatannya sendiri. Kadang juga ada anak yang lebih jahil dan nakal yang suka merusak hasil karya temannya sendiri atau mencoretcoret gambar teman lainnya. Bahkan kadang ada juga minta bantuan orang tua dan guru atau temannya untuk menyelesaikan kreatifitasnya. Jadi dalam kaitannya hal tersebut, sentra seni memiliki pengaruh terhadap perkembangan sosial emosional anak.

Dalam kenyataan yang ada dilapangan tersebut maka penelitian mengambil judul “ Pengaruh Sentra seni terhadap perkembangan social emosional anak pada RA Roudlotul 
Hamdi Rembang Tahun Ajaran 2016/2017" Karena dalam berkreatifitas seni akan ada banyak manfaat yang bisa di gunakan anak ketika mereka sudah berada di jenjang pendidikan yang lebih tinggi maupun ketika berinteraksi dengan masyarakat yang luas.

\section{METODE PENELITIAN}

Populasi adalah keseluruhan dari obyek atau subyek yang diteliti oleh peneliti yang memiliki karakteristik yang sama dan ciricirinya dapat diduga. populasi dari penelitian ini adalah kelompok A dengan jumlah sample 20 siswa. Hasil penelitian yang telah dilaksanakan beserta pembahasannya, yang secara garis besar akan diuraikan tentang deskripsi data, pengujian sebelum dan sesudah perlakukan (treatment) pada Pembelajaran Sentra seni dan kreatifitas. Penelitian ini merupakan penelitian eksperimen yang bertujuan untuk mengetahui pengaruh pembelajaran sentra Seni dan Kreativitas terhadap perkembangan sosial emosional anak kelompok A.

Penelitian ini menggunakan 1 (satu) variabel bebas yaitu perkembangan sosial emosional yang memiliki 20 pernyataan . Sampel penelitian ini dibagi menjadi dua kelompok yaitu kelompok ekperimen dan kelompok kontrol. Uji statistik yang digunakan pada penelitian ini adalah uji validitas menggunakan rumus korelasi product momen, Uji reliabilitas menggunakan alpha cronbach, Uji normalitas wilcoxon signed rank test dan uji hipotesis menggunakan Analisis wilcoxon.

Setelah melalui proses penelitian dengan melakukan kegiatan pembelajaran menggunakan pembelajaran sentra seni dan kreatifitas, maka terdapat hasil analisis data observasi kegiatan pembelajaran. Data Skor yang diperoleh dideskripsikan dengan mentabulasikan menurut masingmasing variabel, dengan bantuan program komputer SPSS diperoleh Skor tertinggi (max), Skor Terendah (min), Mean (Me), Varian (s), Modus (Mo), dan Median (Md). Uji validitas menggunakan pengujian validitas konstruk, dengan cara mengkonsultasikan instrumen dengan dosen ahli (judgment experts). Setelah pengujian konstruk dari dosen ahli selesai, maka diteruskan uji coba instrumen. Setelah data ditabulasikan, maka pengujian validitas konstruk dilakukan dengan analisis faktor, yaitu dengan mengkorelasikan antar skor item instrumen, analisis faktor menggunakan rumus korelasi Product Moment yaitu Rumus Korelasi Product Moment :

$$
r_{x y}=\frac{N \Sigma x y_{-(\Sigma x)}(\Sigma y)}{\sqrt{\left(N \Sigma x^{2}-\left(\sum x\right)^{2}\left(N \Sigma y^{2}-(\Sigma y)^{2)}\right.\right.}}
$$

Program yang digunakan adalah program SPSS. Teknik pengujian menggunakan korelasi Bivariate Pearson (Produk Momen Pearson). Analisis ini dengan cara mengkorelasikan masing-masing skor item dengan 
skor total. Skor total adalah penjumlahan dari keseluruhan item. Item-item pertanyaan yang berkorelasi signifikan dengan skor total menunjukkan item-item tersebut mampu memberikan dukungan dalam mengungkap apa yang ingin diungkap à Valid. Jika $r$ hitung $\geq r$ tabel (uji 2 sisi dengan sig. 0,05) maka instrumen atau item-item pertanyaan berkorelasi signifikan terhadap skor total (dinyatakan valid).

Pengujian reliabilitas instrumen dengan menggunakan rumus Alpha Cronbach karena instrumen penelitian ini berbentuk angket dan skala bertingkat. Rumus Alpha Cronbach sebagai berikut

$$
r_{11}=\left(\frac{n}{n-1}\right)\left(1-\frac{\sum \sigma_{t}^{2}}{\sigma_{t}^{2}}\right)
$$

Jika nilai alpha $>0.7$ artinya reliabilitas mencukupi (sufficient reliability) sementara jika alpha > 0.80 ini mensugestikan seluruh item reliabel dan seluruh tes secara konsisten memiliki reliabilitas yang kuat.

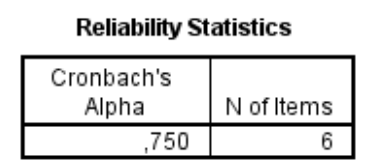

Nilai Cronbach's Alpha sebesar 0.750 yang menunjukan bahwa ke-6 pernyataan cukup reliable

\section{HASIL DAN PEMBAHASAN}

Dalam uji ini Peneliti ingin mengetahui Pengaruh Penerapan Pembelajaran Sentra Seni dan
Kreatifitas, terhadap Perkembangan Sosial Emosional Anak Untuk kebutuhan data, peneliti melakukan penilain sebelum (pre-test) dan sesudah (post-test) dilakukan treatment yaitu penerapan pembelajaran sentra Seni dan Kreatifitas.

Dari uraiana diatas penulis menyimpulkan Angka pada Negative Ranks atau selisih (negative), N, Mean Rank dan Sum of Ranks adalah 0, yang artinya antara penerapan pembelajaran sentra Seni dan Kreatifitas untuk pre-test dan post-test menunjukkan tidak ada penurunan (pengurangan) dari nilai pre-test ke nilai post-test.Positive Ranks atau selisih (positif) antara pre-test dan post-test, menunjukkan angka 20 positif $(\mathrm{N})$ yang artinya ke 20 siswa mengalami peningkatan skor (nilai) dari nilai pre-test ke nilai post-test, Mean Rank atau rata-rata peningkatan sebesar 26,00, sedangkan Sum of Ranks atau jumlah rangking positif sebesar 356,00, Menunjukkan peningkatan skor perkembangan Sosialemosionalanak sebelum dan sesudah menerapkan pembelajaran sentra Seni dan Kreatifitas. Ties adalah nilai kesamaan pre-test dan post-test, disini menunjukkan nilai 0 , yang artinya tidak ada nilai yang sama antara pre-test dan post-test ini menunjukkan ada perbedaan nilai perkembangan Sosialemosional sebelum penerapan sentra dan sesudah penerapan sentra Seni dan kreatifitas nilai atau skor yang diambil dari sebelum dan sesudah 
diterapkan pembelajaran sentra Seni

dan Kreatifitas menunjukkan peningkatan dari semua siswa.

Nilai

peningkatan

perkembangan

social

emosionalanakdari ke 20 siswa yang

telah dilakukan penerapan

pembelajaran sentra Seni dan

Kreatifitas rata-rata skor atau nilai meningkat 26.00Test Statistics diatas nilai Asymp. Sig (2-tailed) adalah 0 , Karena nilai Asymp. Sig (2-tailed) lebih kecil dari 0.005 maka ada pengaruh yang signifikan perkembangan social emosionalanak sebelum dan sesuadah penerapan pembelajaran sentra Seni dan Kreatifitas. Dilihat dari hasil analisis angka-angka statistik yang dihasilkan melalui Uji Wilcoxon hasilnya adalah bahwa Penerapan Pembelajaran Sentra Seni dan Kreatifitas berpengaruh terhadap peningkatan perkermbangan senidankreatifitasanak di RA RoudlotulHamdiRembang".Pembelaj aran Sentra Seni dan Kreatifitas sangat efektif untuk meningkatkan perkembangan social emosional anak khususnya.

Berdasarkan hasil analisa data, maka selanjutnya penulis menyimpulkan "ada pengaruh pembelajaran sentra sains terhadap perkembangan sosial emosional anak kelompok A di RA. Roudlotul Hamdi Rembang ". Besar perbandingan perkembangan sosial emosional anak dengan melakukan pembelajaran sentra dan tanpa sentra adalah 26,00 (tanpa menggunakan sentra) dan 356,00 (menggunakan sentra)

\section{SIMPULAN.}

Berdasarkan hasil analisa data, maka selanjutnya penulis menyimpulkan "ada pengaruh pembelajaran sentra sains terhadap perkembangan sosial emosional anak kelompok A di RA. Roudlotul Hamdi Rembang ".

Besar perbandingan perkembangan sosial emosional anak dengan melakukan pembelajaran sentra dan tanpa sentra adalah 26,00 (tanpa menggunakan sentra) dan 356,00 (menggunakan sentra)

\section{DAFTAR PUSTAKA}

Arikunto,S.2006.Prosedur penelitian suatu pendekatan praktek. Jakarta:Rineka cipta

Dr.Yuliani Nurani Sujiono 1992.Konsep dasar pendidikan anak usia dini.

Sri Uning Puji Utami. 2014. Peningkatan kreativitas seni Melalui bermain membentuk bebas terarah Pada anak kelompok $b$ di tk pedagogia Yogyakarta

Shapiro,LE 1999. Mengajarkan Emotional Intellegence Pada anak. Jakarta PT Citra Angakasa

Slavin, Robert E. 2008, Psikologi pendidikan teori dan Praktek Edisi kedelapan jilid 1, Jakarta $\mathrm{PT}$ indeks

Sugiyono,2012. Metode Penelitian Kuantitatif Kualitatif dan $R \& D$ Bandung: Alfabeta

Sujiono. Yuliani Nurani2013. Konsep Dasar pendidikan Anak Usia dini, Jakarta PT Indenks

Sumarsono Sonny, 2004 Metode Riset Sumber Daya Manusia 
Yogyakarta : Graha Ilmu.

Supranata. S. 2005. Analisis

Validitas. Reliabilitas Dan interpretasi Hasil Tes.

Implementasi Kurikulum 2004,

Bandung : Remaja Rosdakarya

Susanto Ahmad. 2012.

Perkembangan Anak Usia Dini.

Jakarta: kencana Prenada media

Grup

Suyanto, DKK. 2003. Bermain dan permainan Anak, Jakarta: Universitas terbuka Yudhistira, Siska Y.M.2012. Pendidikan Karakter dengan Metode Sentra Jakarta: Media pustaka sentra.

http://ejurnal.fip.ung.ac.id/index.php /PDG/article/viewFile/195/190/: Kamis, 11:40 